\title{
UTILIZATION OF POND FLY ASH AS A PARTIAL REPLACEMENT IN FINE AGGREGATE WITH USING FINE FLY ASH AND ALCCOFINE IN HSC
}

\author{
Jay Patel ${ }^{1}$, Kunal Patel ${ }^{2}$, Gaurav Patel ${ }^{3}$ \\ ${ }^{1,2}$, Department of Structural Engineering, B.V.M, Gujarat, India \\ ${ }^{3}$ Post graduate Student, Department of Construction Engineering \& Management, B.V.M, Gujarat, India \\ jay.skpatel@gmail.com,patel.kunal1990@hotmail.com,gauravinmehsana@gmail.com
}

\begin{abstract}
Due to increase in the growth of industrial sectors the power requirement of the country is rapidly increasing. India depends on Thermal Power as its main source, thus increase in power requirement every year. Present scenario of our country shows $75 \%$ of country's total installed power generation is thermal of which coal-based generation is $90 \%$. The coal reserves of the country are predominately of lower grades (average of 35\% ash content), non cooking and as a result more than 110 million MT coal ash is being generated every year. Ash generation may likely reach to 170 million MT by 2012. Use of coal brings huge amount of ash every year. Lots of research has been carried out for effective utilization of fly ash in construction industries due to its fine particles and Pozzolonic properties. But little literature is available on pond ash utilization. Pond ash being coarser and less Pozzolonic than fly ash can be used as fine aggregates in concrete by partial replacement of sand.
\end{abstract}

As per $M_{60}$ Mix Design in this project we will replace the alccofine and fine fly ash partially with cement and pond fly ash as a replacement of fine aggregate. In mix G1, G2, G3 we will replace cement with alccofine 4\% and fine fly ash $26 \%$ and pond fly ash varies 10\%, 20\%, and 30\% as replacement of F.A. Similarly in mix G4,G5,G6 alccofine 6\% and fine fly ash $24 \%$ and pond fly ash same as 10\%,20\%,30\%. The Concrete specimens will tested at different age level for Mechanical Properties of concrete, namely, Cube Compressive Strength, Split Tensile Strength, Flexural Strength with other properties such as Compacting Factor, with respect to 7,28,56,90 Days strength. The main aim of our study as project is to get the economical and eco friendly High strength Concrete (HSC).

$* * *$

\section{INTRODUCTION}

Pozzolanic concretes are used extensively throughout the world where oil, gas, nuclear and power industries are among the major users. The applications of such concretes are increasing day by day due to their superior structural performance, environmental friendliness, and energy conserving implications. Research has been conducted on the use of fly ash, volcanic ash, volcanic pumice, pulverized-fuel ash, blast slag and silica fume as cement replacement material. Fly ash and others are pozzolanic materials because of their reaction with lime liberated during the hydration of cement. These materials can also improve the durability of concrete and the rate of gain in strength and can also reduce the rate of liberation of heat, which is beneficial for mass concrete. Concretes containing mineral admixtures are used extensively throughout the world for their good performance and for ecological and economic reason.
In the past few years, many research and modification has been done to produce concrete with higher strength and durability.

\subsection{High Strength Concrete}

$>$ It is important to note the high-strength and high performance concrete are not synonymous.

$>$ Concrete is defined as "high-strength concrete" solely on the basis of its compressive strength measured at a given age.

$>$ In the 1970's, any concrete mixtures that showed $40 \mathrm{Mpa}$ or more compressive strength at 28-days were designed as high-strength concrete.

$>$ Later, 60-100 MPa concrete mixtures were commercially developed and used in the construction of high-rise buildings and long-span bridges in many parts of the world

$>$ In normal strength concrete, the micro cracks form when the compressive stress reaches $\sim 40 \%$ of the strength. The 
cracks interconnect when the stress reaches $80-90 \%$ of the strength.

For HSC, Iravani and Macgregor reported linearity of the stress-strain diagram at 65 to 70,75 to 80 and above $85 \%$ of the peak load for concrete with compressive strengths of 65,95 , and $105 \mathrm{MPa}$.

The fracture surface in HSC is smooth. The cracks move without discontinuities between the matrix and aggregates.

Table 1. Typical Classification of concrete

\begin{tabular}{|l|l|}
\hline Normal Strength & $20-50 \mathrm{MPa}$ \\
\hline High Strength & $50-100 \mathrm{MPa}$ \\
\hline Ultra High Strength & $100-150 \mathrm{MPa}$ \\
\hline Especial & $>150 \mathrm{MPa}$ \\
\hline
\end{tabular}

\section{MATERIAL USED}

\subsection{Cement}

Table 2. OPC 53 grade propeties to IS: 8112-1939

\begin{tabular}{|c|c|c|l|}
\hline Sr no. & characters & result & $\begin{array}{c}\text { As per IS: } \\
\mathbf{8 1 1 2 - 1 9 3 9}\end{array}$ \\
\hline 1 & Specific Gravity & 3.14 & 3.15 \\
\hline 2 & Initial Setting Time & $\begin{array}{c}35 \\
\text { Min }\end{array}$ & $>30$ Min \\
\hline 3 & Final Setting Time & $\begin{array}{c}225 \\
\text { Min }\end{array}$ & $<600$ Min \\
\hline 4 & Fineness of cement & $10 \%$ & $10 \%$ \\
\hline 5 & Compressive Strength & 23.5 & $>23$ \\
& $\begin{array}{c}3 \text { days } \\
7 \text { days }\end{array}$ & 35.8 & $>33$ \\
& 28 days & & \\
\hline
\end{tabular}

\subsection{Fly Ash}

Table 3. Pond fly ash physical properties

\begin{tabular}{|l|l|}
\hline Property & Pond Aash \\
\hline Specific gravity & $2.1-2.7$ \\
\hline Dry Unit Weight & $7.07-15.72 \mathrm{KN} / \mathrm{m} 3$ \\
\hline Plasticity & None \\
\hline Absorption & $0.8-2.0 \%$ \\
\hline
\end{tabular}

Table 4. Pond fly ash chemical properties

\begin{tabular}{cc|c|c|} 
Srno & Type of test & Test Method & Result \\
\hline 1 & $\mathrm{CaO} \%$ & IS-1727 & 0.25 \\
2 & $\mathrm{SiO} 2 \%$ & IS-1727 & 73.6 \\
\hline 3 & $\mathrm{~A} 12 \mathrm{O} \% \%$ & IS-1727 & 9.1 \\
4 & $\mathrm{MgO} \%$ & IS-1727 & 0.05 \\
\hline 5 & $\mathrm{SO} 3 \%$ & IS-1727 & 0.01 \\
\hline 6 & $\mathrm{NaO} \%$ & IS-4032 & 0.004 \\
7 & $\mathrm{~K} 2 \mathrm{O} \%$ & IS-4032 & 0.002 \\
\hline 8 & Total Chloride\% & IS-12423 & 0.002 \\
9 & $\mathrm{~L} .0 . \mathrm{I}$ & IS-1727 & 3.7 \\
\hline 10 & Fe2O3\% & IS-4031 & 1.35 \\
11 & $\mathrm{TiO} 2 \%$ & IS-4031 & $\mathrm{Ni1}$ \\
\hline 12 & $\mathrm{P} 2 \mathrm{O} 3 \%$ & IS-4031 & 0.0001 \\
\hline
\end{tabular}

Table 5. fine fly ash physical properties

\begin{tabular}{|ccc|} 
Sr. & Characteristic & Results \\
no & Lime reactivity, N/mm2 & $8 \mathrm{~min}$ \\
1 & Retention On 25 Micron Sieve & $>0.5$ \\
2 & Drying Shrinkage, percentage & 0.06 \\
\hline 3 & Specific gravity & 0.05 \\
4 & Soundness by Autaclave expansion, percent & 2.2 \\
\hline 5 & Compressive Strength, as percent of strength & 80 \\
6 & of corresponding plain cement mortar cubes &
\end{tabular}

Table 6. Chemical Composition of Fine Fly ash

\begin{tabular}{|c|c|c|c|}
\hline İ No & Type of test & $\begin{array}{l}\text { Test } \\
\text { Method }\end{array}$ & $\begin{array}{l}\text { Result } \\
\text { obtained }\end{array}$ \\
\hline 1 & $\mathrm{CaO} \%$ & IS-1727 & 0.50 \\
\hline 2 & $\mathrm{SiO}_{2} \%$ & IS -1727 & 67.60 \\
\hline 3 & $\mathrm{Al}_{2} \mathrm{O}, \%$ & IS -1727 & 11.30 \\
\hline 4 & $\mathrm{MgO} \%$ & IS -1727 & 0.10 \\
\hline 5 & $\mathrm{SO}, \%$ & IS- 1727 & 0.06 \\
\hline 6 & $\mathrm{NaO}_{2} \%$ & IS -4032 & 0.035 \\
\hline 7 & $\mathrm{~K}_{2} \mathrm{O} \%$ & IS -4032 & 0.005 \\
\hline 8 & Tota1 Chloride\% & IS -12423 & 0.008 \\
\hline 9 & $\begin{array}{l}\text { Loss on } \\
\text { Ignition\% }\end{array}$ & IS -1727 & 2.60 \\
\hline 10 & $\mathrm{Fe}_{2} \mathrm{O}_{2} \%$ & IS -4031 & 1.15 \\
\hline 11 & $\mathrm{TiO}{ }_{2} \%$ & IS -4031 & Ni1 \\
\hline 12 & $\mathrm{P}_{2} \mathrm{O}_{2} \%$ & IS -4031 & 0.0002 \\
\hline
\end{tabular}




\subsection{Alccofine}

Table 7. Physical Properties of Alccofine

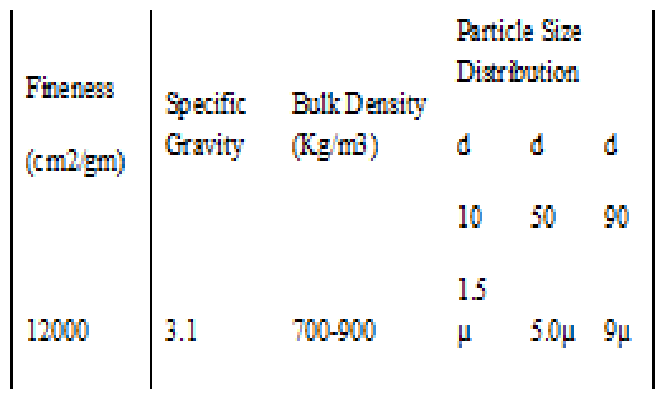

Table 8. Chemical Composition of Alccofine

\begin{tabular}{|l|lllll|l}
$\mathrm{CaO}$ & $\mathrm{S} 03$ & $\mathrm{Si0} 2$ & $\mathrm{AL20}$ & $\mathrm{Fe} 203$ & $\mathrm{MgO}$ & $\mathrm{Cl}$ \\
\hline $61-$ & $2-$ & $21-$ & $5-$ & $3.8-$ & $0.8-$ & $0.03-$ \\
$64 \%$ & $2.4 \%$ & $23 \%$ & $5.6 \%$ & $4.4 \%$ & $1.4 \%$ & $0.05 \%$ \\
\hline
\end{tabular}

\subsection{Fine Aggregate}

Natural sand with a $4.75-\mathrm{mm}$ maximum size was used as a fine aggregate. It was tested as per Indian Standard Specifications IS: 383-1970. Its properties are shown in Table.

\subsection{Coarse Aggregate}

Coarse aggregate used in this study were $20-\mathrm{mm}$ nominal size, and were tested as per Indian Standard Specifications IS 3831970.

Table 9. Physical properties of aggregates

\begin{tabular}{|lll|} 
Property & $\begin{array}{l}\text { Fine } \\
\text { Aggregate }\end{array}$ & $\begin{array}{l}\text { Coarse } \\
\text { Aggregate }\end{array}$ \\
Specific gravity & 2.63 & 2.61 \\
\hline $\begin{array}{l}\text { Fineness } \\
\text { modulus }\end{array}$ & 2.25 & 6.61 \\
\hline $\begin{array}{l}\text { SSD absomption } \\
\text { (\%) }\end{array}$ & 0.86 & 1.12 \\
\hline $\begin{array}{l}\text { Void (\%) } \\
\text { Unit weight }\end{array}$ & 36.2 & 39.6 \\
(kg/m3) & 1690 & 1615 \\
\end{tabular}

\section{MIX PROPORTIONS}

Six mixture proportions were made. So in this project we will replace the alccofine and fine fly ash partially with cement and pond fly ash as a replacement of fine aggregate. In mix G1, G2, G3 we will replace cement with alccofine $4 \%$ and fine fly ash $26 \%$ and pond fly ash varies 10\%, 20\%, 30\% as replacement of fine aggregate. Similarly in mix G4,G5,G6 alccofine $6 \%$ and fine fly ash $24 \%$ and pond fly ash same as $10 \%, 20 \%, 30 \%$. In mix GA we will replace cement with alccofine $4 \%$ and fine fly ash $26 \%$. Similarly in mix GB alccofine $6 \%$ and fine fly ash $24 \%$ Show in table 10 .

Table 10. Mix Proportion

\begin{tabular}{c|cc|c|ccc|cc}
\hline M 60 & G1 & G2 & G3 & G4 & G5 & G6 & GA & GB \\
\hline Cement(kg) & 420 & 420 & 420 & 420 & 420 & 420 & 420 & 420 \\
\hline Fly ash(kg) & 156 & 156 & 156 & 144 & 144 & 144 & 156 & 144 \\
\hline Aalcofme(kg) & 24 & 24 & 24 & 36 & 36 & 36 & 24 & 36 \\
\hline Water(kg) & 198 & 210 & 221 & 198 & 210 & 221 & 179 & 179 \\
\hline F.a(kg) & 676.8601 .6 & 526.4 & 576.8601 .6526 .4 & 752 & 752 \\
\hline P.a(kg) & 75.2 & 150.4 & 225.6 & 75.2 & 150.4225 .6 & - & - \\
C.a(20) (kg) & 672 & 672 & 672 & 672 & 672 & 672 & 672 & 672 \\
C.a(10) (kg) & 448 & 448 & 448 & 448 & 448 & 448 & 448 & 448 \\
Admixr(kg) & 5.3 & 5.3 & 5.3 & 5.3 & 5.3 & 5.3 & 5.3 & 5.3 \\
W/b & 0.33 & 0.35 & 0.37 & 0.33 & 0.35 & 0.37 & 0.2630 .263 \\
\hline
\end{tabular}

\begin{tabular}{|c|c|c|c|}
\hline M60 & ALC COFINE & $\begin{array}{c}\text { FINE } \\
\text { FLY } \\
\text { A SH }\end{array}$ & $\begin{array}{c}\text { POND } \\
\text { FLY } \\
\text { ASH }\end{array}$ \\
\hline G1 & $4 \%$ & $26 \%$ & $10 \%$ \\
\hline G2 & $4 \%$ & $26 \%$ & $20 \%$ \\
\hline G3 & $4 \%$ & $26 \%$ & $30 \%$ \\
\hline G4 & $6 \%$ & $24 \%$ & $10 \%$ \\
\hline G5 & $6 \%$ & $24 \%$ & $20 \%$ \\
\hline G6 & $6 \%$ & $24 \%$ & $30 \%$ \\
\hline GA & $4 \%$ & $26 \%$ & $0 \%$ \\
\hline GB & $6 \%$ & $24 \%$ & $0 \%$ \\
\hline
\end{tabular}




\section{TEST \& RESULTS}

\subsection{Marsh Cone Test}

Cement $=70 \%$ Fly-Ash $=22 \%$ Alccofine $=8 \%$

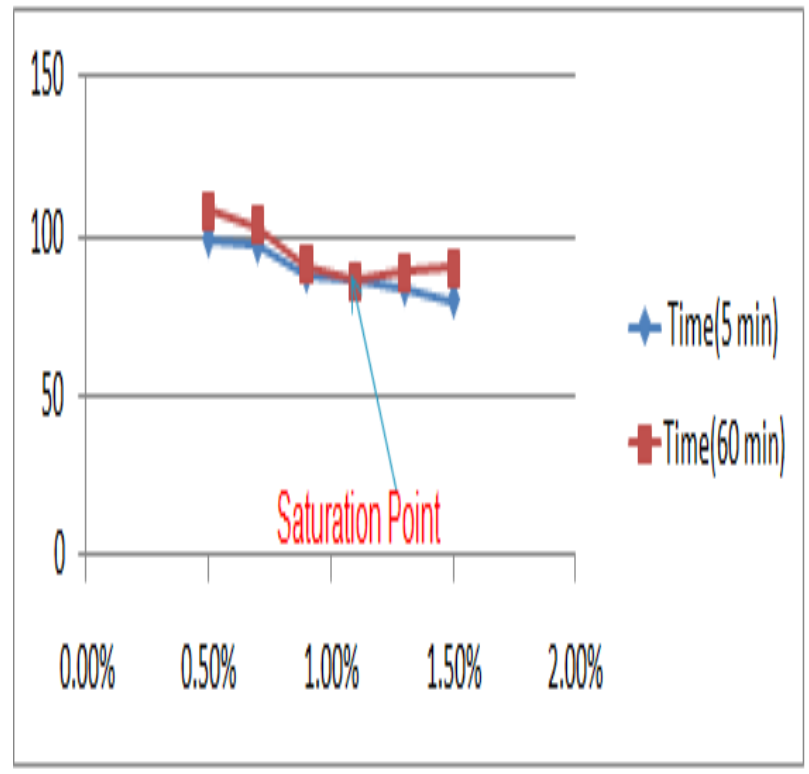

Fig 1. Graph of mash cone test

\subsection{Rebound Hammer}

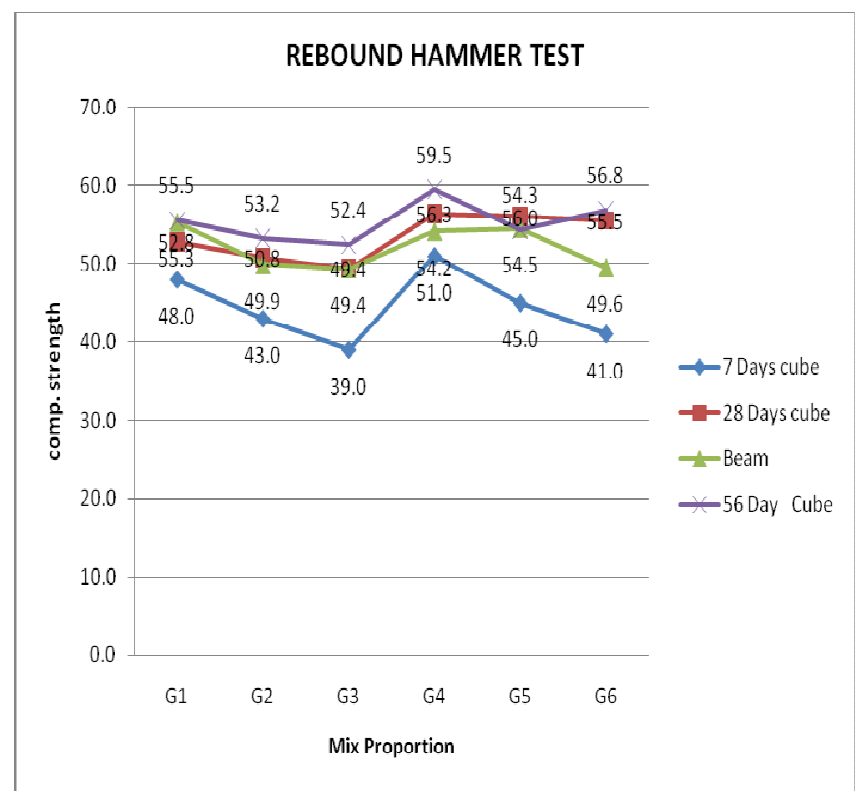

Fig 2. Graph of comp. Strength of 7,28\&56 days cube \& 28days beam
Table 11. Compressive Strength of 7,28\&56 days cube \& 28days beam

\begin{tabular}{|c|c|c|cc} 
Mix Pro. & 7 Day & 28 Day & 56 Day & Beam \\
G1 & 48.0 & 52.8 & 55.5 & 55.3 \\
G2 & 43.0 & 50.8 & 53.2 & 49.9 \\
\hline G3 & 39.0 & 49.4 & 52.4 & 49.4 \\
\hline G4 & 51.0 & 56.3 & 59.5 & 54.2 \\
\hline G5 & 45.0 & 56.0 & 54.3 & 54.5 \\
\hline G6 & 41.0 & 55.5 & 56.8 & 49.6 \\
\hline
\end{tabular}

\subsection{Ultrasonic Pulse Velocity Test}

Table 12. U.P.V results of 7,28 days cube $\& 28$ days beam

\begin{tabular}{|c|ccc|}
$\begin{array}{c}\text { Mix } \\
\text { Proportion }\end{array}$ & $\begin{array}{c}\text { Cube } \\
\mathbf{7} \text { day }\end{array}$ & $\begin{array}{c}\text { Cube } \\
\text { day }\end{array}$ & Beam \\
\hline G1 & 4.26 & 4.17 & 4.03 \\
G2 & 4.24 & 4.41 & 4.17 \\
G3 & 4.17 & 4.55 & 4.07 \\
\hline G4 & 4.52 & 4.23 & 3.99 \\
G5 & 4.39 & 4.42 & 4.05 \\
G6 & 4.26 & 4.19 & 3.95 \\
\hline
\end{tabular}

Table 13.Velocity criteria as per IS-13311 (part1)1992

\begin{tabular}{|c|cc|}
\hline Sr. No & $\begin{array}{c}\text { Pulse velocity } \\
\text { by Cross } \\
\text { Probing } \\
(\mathrm{Km} / \mathrm{sec})\end{array}$ & $\begin{array}{c}\text { Concrete } \\
\text { Qua lity } \\
\text { Grading }\end{array}$ \\
\hline 1 & Above 4.5 & Excellent \\
\hline 2 & 3.5 to 4.5 & Good \\
3 & 3.0 to 3.5 & Medium \\
\hline 4 & Below 3.0 & Doubtful \\
\hline
\end{tabular}




\subsection{Compressive Strength of Cube}

Table 14. Compressive strength results of $7,28 \& 56$ days cube

\begin{tabular}{c|ccc} 
MIX & 7-DAY & 28-DAY & 56-DAY \\
& MPa & Mpa & MPa \\
\hline G1 & 39.5 & 38.80 & 60.77 \\
\hline G2 & 36.5 & 42.00 & 61.17 \\
\hline G3 & 32 & 40.20 & 51.05 \\
G4 & 50.40 & 62.00 & 70.76 \\
G6 & 46.3 & 55.90 & 65.43 \\
G6 & 42.1 & 59.40 & 68.58 \\
GA & 47.36 & 58.82 & 72.9 \\
\hline GB & 54.67 & 63.45 & 66.12 \\
\hline
\end{tabular}

7,28 \&56-DAYCOMPRESSIVESTRENGTH(N/mm2)

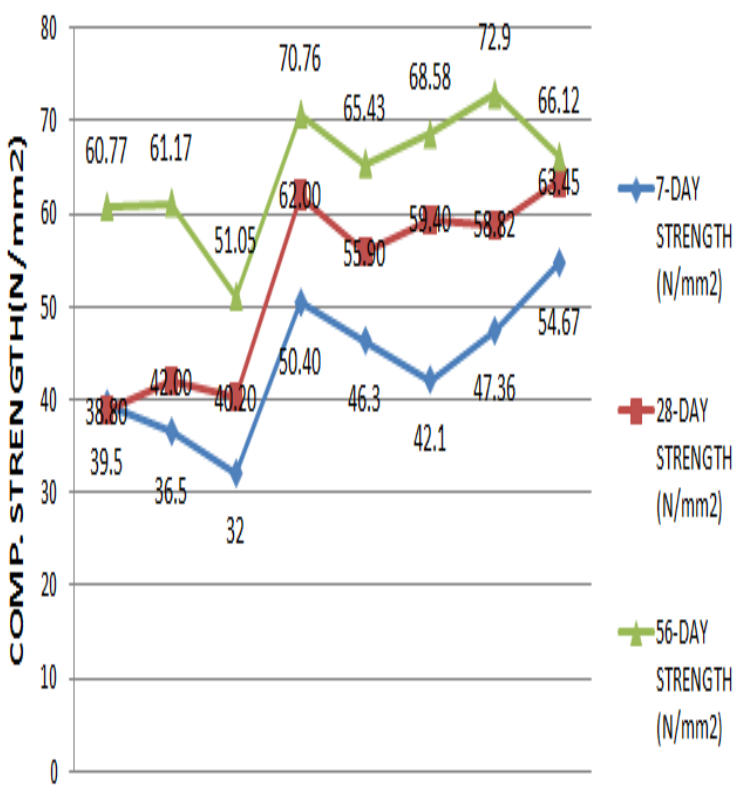

G1 $\quad$ G2 $\quad$ G3 $\quad G 4 \quad G 5 \quad G 6 \quad G A \quad G B$

MIXPRAPORTION

\subsection{Split Tensile Strength of Cylinder}

Table 15. Tensile strength results of $28 \& 56$ days cylinder

\begin{tabular}{cccc|} 
MIX & 28-DAY & 56-DAY & LIMT \\
G1 & 3.57 & 4.79 & 5.42 \\
\hline G2 & 3.76 & 4.13 & 5.42 \\
\hline G3 & 2.89 & 4.71 & 5.42 \\
G4 & 3.98 & 4.70 & 5.42 \\
G5 & 3.46 & 4.24 & 5.42 \\
\hline G6 & 4.49 & 5.13 & 5.42 \\
GA & 4.32 & 5.34 & 5.42 \\
GB & 3.95 & 5.33 & 5.42
\end{tabular}

56-DAYSPLITTING TENSIESTREENGTH (N/mm2)

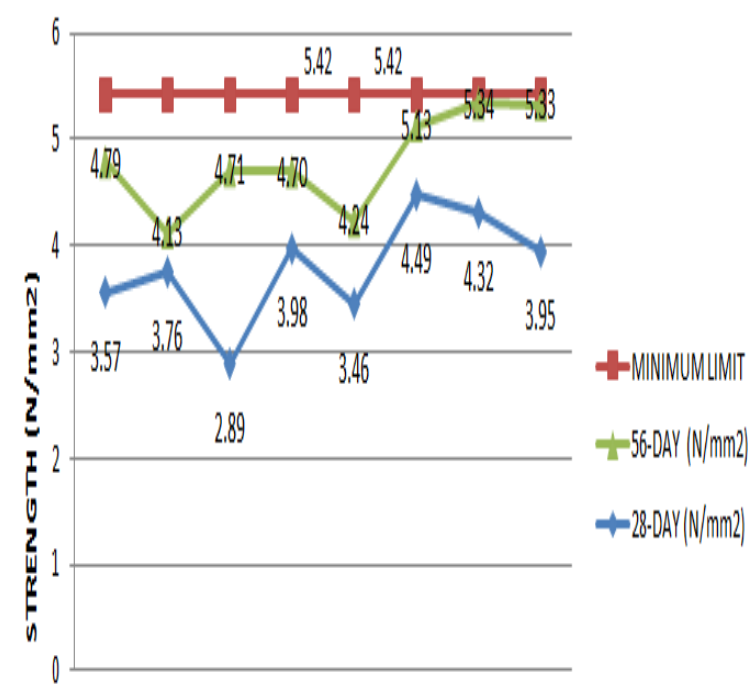

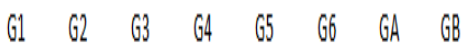

MIXPAPPRTION

Fig 5. Graph of tensile Strength of 28\&56 days cylinder with permissible limit

Fig 4. Graph of comp. Strength of 7,28\&56 days cubes 


\subsection{Flexural Bending Strength of Beam}

Table 16.Flexural bending strength results of 28 days beam
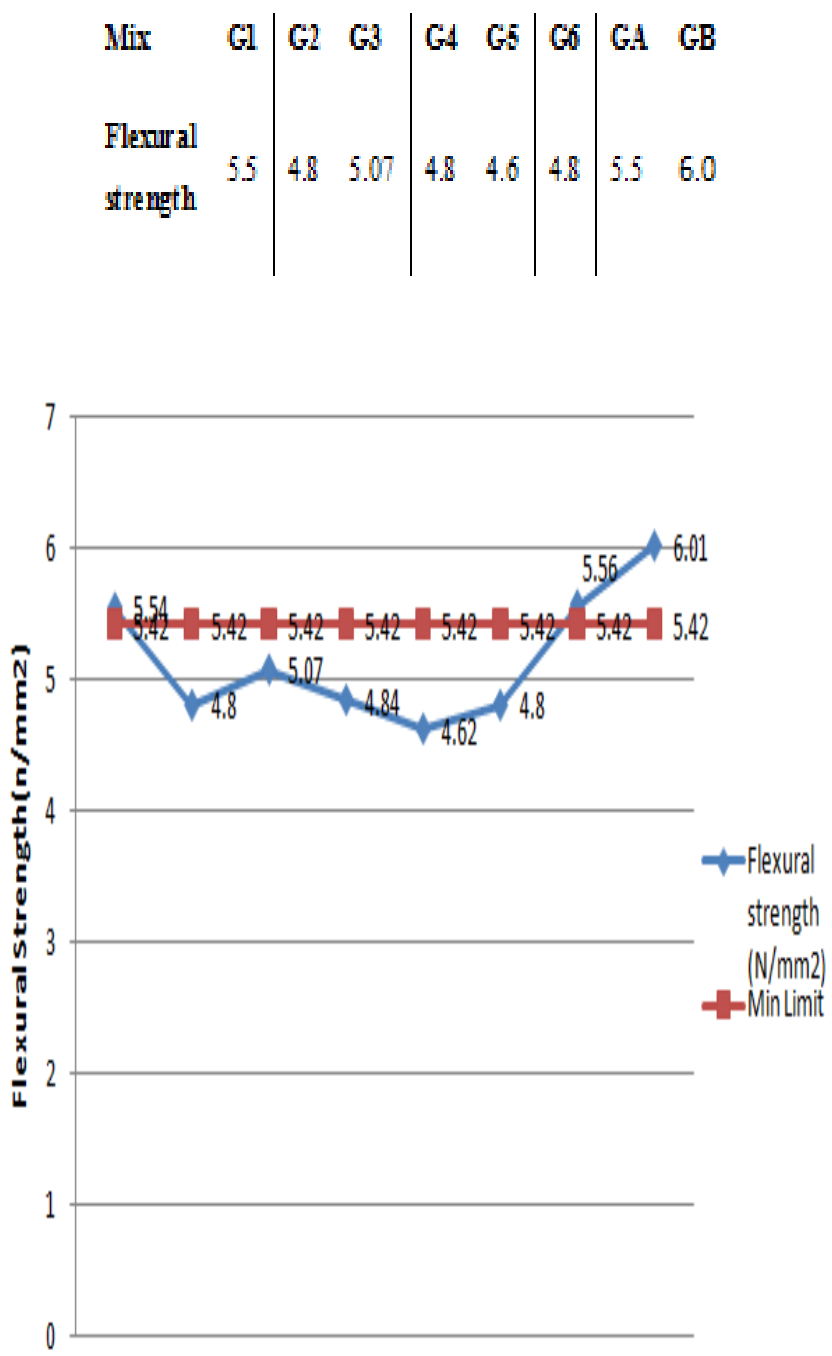

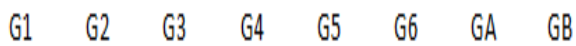
MixProportion

Fig 6. Graph of flexurer Strength of 28 days beam with permissible limit

\section{CONCLUSIONS}

\subsection{Workability}

$>$ The workability of concrete decreased with the increase in Pond fly ash content due to the increase in water demand, which is incorporated by increasing the dosage of Super plasticizer

\subsection{Compressive Strength}

$>\mathrm{We}$ are getting highest strength for using $6 \%$ alccofine as a cement replacement and $10 \%$ pond ash as a replacement in fine aggregate.

$>$ We get $50.4 \mathrm{Mpa}$ compressive strength at 7 days and 62.0 Mpa compressive strength at 28 days for water curing samples and 67.7 Mpa compressive strength at 28 days for self curing samples for above mentioned usage

\subsection{Flexural Strength}

$>\mathrm{We}$ are getting 4.84Mpa flexural strength for $6 \%$ alccofine and $10 \%$ pond ash usage at 28 days

$>$ The Flexural strength of cylinder we concluded that we are not getting tensile strength up to desired limits of $5.42 \mathrm{Mpa}$

\subsection{Splitting Tensile Strength}

$>$ We are getting 3.98 Mpa splitting tensile strength for $6 \%$ alccofine and $10 \%$ pond ash usage at 28 days.

$>$ The split tensile strength of cylinder we concluded that we are not getting tensile strength up to desired limits of $5.42 \mathrm{Mpa}$

$>$ In area like Mumbai , Kerala ,Goa where the pond ash is easily available with low cost than the fine aggregate, the use of pond ash as replacement of sand highly beneficial as well as reducing environmental problems.

\section{REFRENCES}

[1]. IS 8112 - 1989 Specification for 43grade Ordinary Portland Cement, Bureau of Indian Standards, New Delhi.

[2]. IS 383: 1970-Specification for coarse and fine aggregates from natural sources for concrete, Bureau of Indian Standards,New Delhi.

[3]. IS 2386 (Part I-VIII) -1960, Indian standards method of testing for concrete, (First revision), Bureau of Indian Standards, New Delhi, India.

[4]. IS 10262:2009, Indian standard concrete mix proportioning - Guidelines (First revision), Bureau of Indian Standards, New Delhi, India.

[5]. ACI 211.1. (1993). Standard practice for selecting proportions for normal, heavyweight and mass concrete. ACI Manual of Concrete Practice, $38 \mathrm{p}$.

[6]. ASTM C39 (1994). Standard test method for compressive strength of cylindrical concrete specimens, Annual Book of ASTM Standards.

[7]. Demirel B, Yazicio_lu S (2008). Thermoelectric behavior of carbon fiber reinforced lightweight concrete with mineral admixtures. New Carbon Mater., 23(1): 21-24.

[8]. Erdogan T (2003). Concrete, METU Press. p. 741. (in Turkish) Gonen T, Yazicioglu S (2007). The influence of 
mineral admixtures on the short and long-term performance of concrete. Build Environ.,42(8): 3080-3085.

[9]. Sonerbi M., Bartos PJM., ZHU W., Gibbs J., Tamimi A., (2000), "Task 4-properties of hardened concrete", Final report, Brite EuRam Project No. BE963801/Contact

[10]. "Recommended Guidelines for Concrete Mix Design", IS 10262 -2009, Bureau of Indian standards, New Delhi.

[11]. "Plain And Reinforced Concrete -Code Of Practice", IS 456- 2000, Bureau of Indian standards, New Delhi

[12]. "Specification For Coarse And Fine Aggregates From Natural Sources For Concrete", IS 383-1970, Bureau of Indian standards, New Delhi

[13]. "Specification For Fly Ash For Use As Pozzolana And Admixture", IS 3812-1981, Bureau of Indian standards, New Delhi

[14]. "Methods of Test For Aggregate For Concrete", IS 2386(Part 3)-1963, Bureau of Indian standards, New Delhi

[15]. "Non-Destructive Testing Of Concrete -Methods Of Test", IS 13311( PART-1)-1992, Bureau of Indian standards, New Delhi

[16]. Methods Of Tests For Strength Of Concrete", IS 516 1959, Bureau of Indian standards, New Delhi

[17]. "Concrete Admixture- Specification", IS 9103-1999, Bureau of Indian standards, New Delhi

[18]. "43 Grade Ordinary Portland Cement - Specification" IS

8112-1989, Bureau of Indian standards, New Delhi 